\title{
EXPLOSIVE MUSCLE POWER ASSESSMENT IN ELITE ATHLETES USING WINGATE ANAEROBIC TEST
}

\author{
AVALIAÇÃO DA FORÇA MUSCULAREXPLOSIVA EM ATLETAS DE ELITE USANDO O TESTE \\ ANAERÓBICO DE WINGATE
}

Original Article

ARTIGO ORIGINAL

Artículo Original

\section{EVALUACIÓN DELA FUERZA MUSCULAREXPLOSIVA EN ATLETAS DE ÉLITE USANDO LAPRUEBA ANAERÓBICA DE WINGATE}

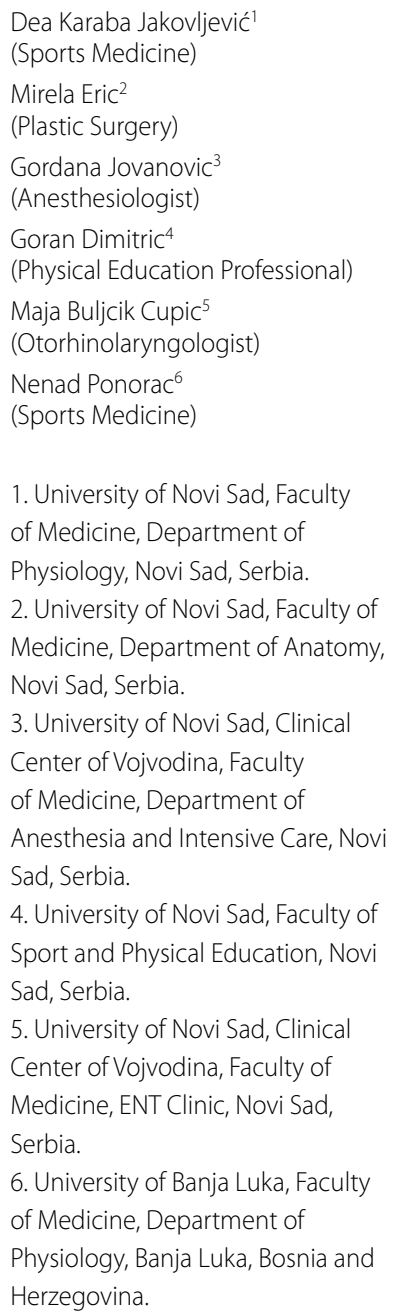

\section{Correspondence:}

Department of Physiology, Faculty of Medicine, University of Novi Sad, Hajduk Veljkova 3, 21000

Novi Sad, Serbia.

dea.karaba-jakovljevic@mf.uns.ac.rs

\begin{abstract}
Introduction: Maximal effort physiological tests provide information about the current functional capacity of athletes. Objective: The aim of this study was to evaluate anaerobic performance parameters in elite athletes and to compare them in terms of the specific demands of each sport. We also created and applied the new software which enables us to quantify a new parameter -explosive muscle power (EP), a major component in sports requiring explosive bursts of movement lasting from a few seconds to 1 or 2 minutes. This new parameter reflects the velocity of energy transformation from intramuscular ATP and high-energy phosphates into mechanical power. Methods: All Wingate test parameters (standard parameters) - anaerobic power (AP), anaerobic capacity (AC), and explosive power (EP) as the new parameter were recorded in 104 subjects: 30 non-athletes and 74 athletes divided into different groups depending on their sport specialty (20 rowers, 28 wrestlers and 26 soccer players). Results: Anaerobic power (AP), anaerobic capacity (AC) and explosive power (EP) were significantly higher in the group of athletes compared to non-athletes. Among athletes, significant differences were observed in some parameters according to the type of activities they are involved in. The highest values were recorded in the group of wrestlers ( $A P=836 \mathrm{~W} ; A C=16.6 \mathrm{KJ} ; \mathrm{EP}=139 \mathrm{~W} / \mathrm{s}$ ). The values of AP (absolute values) and EP (absolute and relative values) were significantly higher in wrestlers than in soccer players and rowers, but there was no significant difference in AC among these groups. The EP variable had a distribution similar to AP. Conclusions: Alongside anaerobic power and anaerobic capacity, the assessment of explosive power may complement the anaerobic profile of athletes. Experts in the field of sports medicine and exercise physiology could find these results useful in improving test variables, which are more important for specific sports, and for evaluating and monitoring training progress. Level of Evidence l; Diagnostic studies - Investigating a diagnostic test.
\end{abstract}

Keywords: Sports performance; Muscle strength; Muscle contraction; Exercise test; Sports medicine.

\section{RESUMO}

Introdução: Os testes fisiológicos de esforço máximo fornecem informações sobre a capacidade funcional atual dos atletas. Objetivo: O objetivo deste estudo foi avaliar os parâmetros de desempenho anaeróbico em atletas de elite e compará-los em relação às demandas específicas de cada esporte. Além disso, criamos e aplicamos o novo software que possibilita a quantificação de um novo parâmetro - força muscular explosiva (FE), um componente importante em esportes que requerem explosões de movimento que duram de alguns segundos a 1 ou 2 minutos. Este novo parâmetro reflete a velocidade de transformação de energia a partir de ATP e fosfatos de alta energia intramusculares em potência mecânica. Métodos: Todos os parâmetros de teste de Wingate (parâmetros padrão) - potência anaeróbica (PA), capacidade anaeróbica (CA) e força explosiva (FE) como um novo parâmetro foram registrados em 104 indivíduos: 30 não atletas e 74 atletas divididos em diferentes grupos, dependendo da sua especialidade esportiva (20 remadores, 28 lutadores e 26 jogadores de futebol). Resultados: A potência anaeróbica (PA), a capacidade anaeróbica (CA) e a força explosiva (FE) foram significativamente maiores no grupo de atletas em comparação com não atletas. Entre os atletas, diferenças significativas foram observadas em alguns parâmetros, de acordo com o tipo de atividades nas quais eles estão envolvidos. Os valores mais altos foram registrados no grupo de lutadores $(P A=836 \mathrm{~W}, C A=16,6 \mathrm{~kJ}, F E=139 \mathrm{~W} / \mathrm{s}$ ). Os valores de PA (valores absolutos) e FE (valores absolutos e relativos) foram significativamente maiores em lutadores do que em jogadores de futebol e remadores, mas não houve diferenças significativas na CA entre esses grupos. A variável FE mostrou uma distribuição similar à da PA. Conclusões: Juntamente com o poder anaeróbico e a capacidade anaeróbica, a avaliação da força explosiva pode complementar o perfil anaeróbico dos atletas. Especialistas no campo da medicina esportiva e da fisiologia do exercício poderiam achar esses resultados úteis para melhorar as variáveis de teste que são mais importantes para esportes específicos e para avaliar e monitorar o progresso do treinamento. Nível de Evidência l; Estudo diagnóstico - Investigação de um exame para diagnóstico.

Descritores: Desempenho esportivo; Força muscular; Contração muscular; Teste de esforço; Medicina esportiva 


\section{RESUMEN}

Introducción: Las pruebas fisiológicas de esfuerzo máximo proporcionan información sobre la capacidad funcional actual de los atletas. Objetivo: El objetivo de este estudio fue evaluar los parámetros de rendimiento anaeróbico en atletas de élite y compararlos en relación con las demandas especificas de cada deporte. Además, creamos y aplicamos el nuevo software que permite la cuantificación de un nuevo parámetro - fuerza muscular explosiva (FE), un componente grande en deportes que requieren explosiones de movimiento que duran de unos segundos a 102 minutos. Este nuevo parámetro refleja la velocidad de transformación de energía a partir de ATP y fosfatos de alta energía intramusculares en potencia mecánica. Métodos: Todos los parámetros de prueba de Wingate (parámetros estándar) - potencia anaeróbica (PA), capacidad anaeróbica (CA) y fuerza explosiva (FE) como un nuevo parámetro fueron registrados en 104 sujetos: 30 no atletas y 74 atletas divididos en diferentes grupos dependiendo de su especialidad deportiva (20 remeros, 28 luchadores y 26 jugadores de fútbol).Resultados: La potencia anaeróbica (PA), la capacidad anaeróbica (CA) y la fuerza explosiva (FE) fueron significativamente mayores en el grupo de atletas en comparación con los no atletas. Entre los atletas, se observaron diferencias significativas en algunos parámetros según el tipo de actividades en las que están involucrados. Los valores más altos fueron registrados en el grupo de luchadores (PA $=836 \mathrm{~W} ; C A=16,6 \mathrm{~kJ} ; \mathrm{FE}=139 \mathrm{~W} / \mathrm{s}$ ). Los valores de PA (valores absolutos) y FE (valores absolutos y relativos) fueron significativamente mayores en luchadores que en jugadores de fútbol y remeros, pero no hubo diferencias significativas en CA entre estos grupos. La variable FE mostró una distribución similar a la de la PA. Conclusiones: Junto con la potencia anaeróbica y la capacidad anaeróbica, la evaluación de la fuerza explosiva puede complementar el perfil anaeróbico de los atletas. Los expertos en el campo de la medicina deportiva y la fisiología del ejercicio podrían encontrar estos resultados útiles para mejorar las variables de prueba que son más importantes para deportes específicos y para evaluar y monitorear el progreso del entrenamiento. Nivel de Evidencia l; Estudio diagnóstico - Investigación de un examen para diagnóstico.

Descriptores: Rendimiento deportivo; Fuerza muscular; Contracción muscular; Prueba deesfuerzo; Medicina deportiva.

\section{INTRODUCTION}

Assessment of the physical capacities of athletes is one of the most important issues in modern sports, and many tests are used in order to monitor the efficacy of training regimes and improvement of sport performance. The demands in sport are closely related to the athlete's physical capacity, and one of the components is the ability to develop a high power output (force) in single actions during competition. Thus, anaerobic power assessment is an important criterion for the maximal performance in sports in which short-term explosive efforts are made. ${ }^{1}$

When evaluating anaerobic parameters in athletes, a few types of power are of great importance: peak power (represents maximal value of power for a given contraction) can be defined as the ability of the athlete to transform the energy of non oxygen energy systems into power; ${ }^{2}$ explosive power (reflects the velocity of achieving peak power in unit of time); and power endurance that refers to the ability of maintaining maximal power as long as possible. These anaerobic components of energetic capacity can be more or less precisely measured in different ways, mostly by applying tests of maximal physical effort, involving very high intensity exercise lasting between a fraction of a second and several minutes. ${ }^{3,4}$ The Wingate anaerobic 30-s cycle Test (WAnT) is the most popular anaerobic test to date..$^{5-11}$ It determines the maximum anaerobic power and ability to maintain a high power output. In the standard version it does not provide information about how fast AP can be reached. For instance, athletes may have similar values in anaerobic power variable, but totally differ in time reaching maximal power, i.e. explosiveness. The present investigation was therefore designed to work out basic methodological approaches to test the explosive muscle power, by creating and applying a software that would provide information of muscle power in 1/10 fraction of a second with increasing the frequency of power registration. This allowed us to obtain a new parameter. This parameter reflects ultimate potential for explosive movements determined by the fast twitch composition of muscles, and probably by the nature of the ATPase secreted by the cross bridges of fibers. ${ }^{12}$ Since a number of sports require explosive bursts of activity lasting from a few seconds to 1 to 2 minutes, ${ }^{2}$ these values may be used in various training and research programs to more accurately assess and monitor and to compare athlete's level of anaerobic performance. The aim of this study was also to evaluate anaerobic performance parameters in non athletes and athletes engaged in different sport disciplines, and to compare them in relation to specific demands of each sport.

\section{MATERIALS AND METHODS}

Wingate test parameters were investigated in 104 subjects classified into different groups depending on the level of physical activity and sport specialities. Thirty non athletes, twenty rowers, twenty six soccer players and twenty eight wrestlers volunteered to participate in the study. The wrestlers, rowers and soccer players were considered elite athletes since all of them had national and international degrees, and were members of Serbian national teams. Details of the study were explained to all participants and signed informed consent from the investigated subjects was obtained. A self administered questionnaire was used to asses age, participation age to sports and amount of training experience. This investigation was aproved by Ethical Comitee of Medical faculty of Novi Sad (Number of Protocol 584-9-2012) and all participants gave their written consent.

Basic athropometric parameters were recorded (body height, body weight) and Wingate anaerobic test was conducted in all subjects. A 5 min to 10 min intermittent warm-up protocol was administered to all participants prior the test. Then Wingate anaerobic test was applied to all subjects. The WAnT was performed on a cycle ergometer (Monark 824E, Monark, Sweden) in standard version of 30s. ${ }^{13,14}$ Alongside with standard variables measured as markers of anaerobic abilities. ${ }^{2}$ peak power (the highest power output observed during the first few seconds of test, indicates the energy generating capacity of the immediate energy system; and anaerobic capacity (representing 30-s power output, 
obtained by averaging the values obtained during six 5 -s segments, and reflects the local endurance of involved muscles); we applyed a new parameter, explosive power, in order to obtain more information of the slope of power during the test, reflecting explosive characterisics of muscle contractions. All parameters were recorded via software installed in PC, which was directly connected with the ergometer machine and then analysed.

\section{Data analysis}

Descriptive statistics (mean, standard deviation, range) for all data in statistical analysis was applied. We used independent t test method to reveal the difference between investigated groups. We accepted statistical significance as $p<0.05$.

\section{RESULTS}

Basic anthropometric characteristic of rowers, soccer players and wrestlers are shown in Table 1. The means, standard deviations and ranges for each variable are given in table.

Values of Wingate test parameters in investigated groups are shown in Table 2.

Comparing results of anaerobic abilities of non athletes and athletes involved in different types of sports activities, we can observe significant differences in values of all Wingate parameters among investigated groups. Values of anaerobic power (AP), anaerobic capacity (AC) and explosive power (EP) were significantly higher in the group of athletes compared to non athletes. When analyzing the Wingate test parameters of athletes engaded in different sport types, we can observe significantly

Table 1. Basic anthropometric characteristic of rowers, soccer players and wrestlers.

\begin{tabular}{|c|c|c|c|c|}
\hline Subjects & $\begin{array}{l}\text { Height } \\
\text { (cm) }\end{array}$ & $\begin{array}{c}\text { Body } \\
\text { mass }(k g)\end{array}$ & $\begin{array}{c}\text { Age } \\
\text { (years) }\end{array}$ & $\begin{array}{c}\text { Sport experience } \\
\text { (years) }\end{array}$ \\
\hline \multicolumn{5}{|c|}{ Non athletes $(n=30)$} \\
\hline$x$ & 183 & 81.2 & 20.8 & - \\
\hline SD & 6.55 & 9.13 & 1.11 & - \\
\hline Min & 171 & 62 & 19.0 & - \\
\hline $\operatorname{Max}$ & 195 & 110 & 26.0 & - \\
\hline \multicolumn{5}{|c|}{ Rowers $(n=20)$} \\
\hline$x$ & 189 & 85.9 & 19.2 & 5.07 \\
\hline SD & 4.24 & 4.45 & 2.04 & 2.49 \\
\hline Min & 179 & 82 & 17 & 2.00 \\
\hline Max & 195 & 97 & 23 & 10.0 \\
\hline \multicolumn{5}{|c|}{ Soccer players $(n=26)$} \\
\hline$x$ & 182 & 77.6 & 20.9 & 10.2 \\
\hline SD & 4.98 & 5.68 & 2.35 & 2.30 \\
\hline Min & 171 & 70 & 17.0 & 5.00 \\
\hline Max & 194 & 92 & 25.0 & 16.00 \\
\hline \multicolumn{5}{|c|}{ Wrestlers $(n=28)$} \\
\hline$x$ & 177 & 85.1 & 22.2 & 11.2 \\
\hline SD & 7.65 & 17.1 & 3.75 & 5.22 \\
\hline Min & 165 & 61.0 & 17.0 & 2.00 \\
\hline Max & 191 & 121 & 31.0 & 22.0 \\
\hline
\end{tabular}

higher values of anaerobic power, explosive power and relative explosive power in wrestlers as representative of sport with predominantly anaerobic characteristics compared to other groups of athletes. However, we did not identify a statistically significant differences between values of anaerobic capacity ( $p>0.05)$.

\section{DISCUSSION}

Regular, programmed physical activity leads to physical and physiological benefits, and increase in strength and endurance. ${ }^{1}$ Many studies confirmed that continuous, and individually dosed physical activity leads to metabolic adaptations on the level of muscle cell, mostly manifested in the amount and the way of utilization of energetic substrates for muscle contraction. ${ }^{15-19}$ Our results are consistent with other studies that showed that trained individuals have greater anaerobic power, explosive power, and anaerobic capacity compared to sedentary individuals, as a result of chronic adaptation to training. ${ }^{2}$ In many sports, the dominant physical attribute requred for sucess is power or speed power, and the training process is planned to allow the athlete to have maximal power expressed specially to meet the demands of the sport. ${ }^{20}$

In our study, differences in anaerobic parameters according to the type of sport activity were recorded in the group of athletes. Generaly, anaerobic sport representatives (wrestlers) were more successful than soccer players and rowers, which could be explained by the specificity and demands of the sport: wrestling is a complex sport branch, dominantly anaerobic and requires maximal power, strength, agility and flexibility for explosive movements during the competition. When comparing specific Wingate parameters among athletes, our result showed that wrestlers developed the highests power output in Wingate test, and there was significant difference in anaerobic power and relative anaerobic power between wrestlers and other athletes. ${ }^{20}$

Power in wrestlers is related with quick and explosive effort that leads to wrestling success. Anaerobic power and capacity are important in wrestling because of the need of short-duration and high intensity performance, ${ }^{21}$ and Wingate test can be used to reflect the maximum ability of wrestlers to generate power. ${ }^{22}$

Interestingly, there was no significant difference in values of anaerobic capacity among wrestlers, rowers and soccer players indicating that anaerobic endurance plays important role all of these activities. Wrestling is sport where anaerobic activities such as explosive and fast movements are involved more than in soccer, where aerobic component also contributes to energy release in game lasting over 90 minutes. Soccer is considered to be mostly aerobic sport, because of its duration, but when analyzing the structure of the game lasting over 90 minutes, it is obvious that players are involved in variety of different activities such as sprinting, jogging, walking and jumping, where action bouts require maximal physical exertion for brief moments followed by short rest periods. ${ }^{23}$ The great part of soccer match is in intervals which do not last for long periods of time. As numerous studies suggest, the players spend up to $11 \%$ of the game sprinting 24 , and anaerobic sources enable them to carry out high speed runs. The sport is also characterized by numerous explosive short exercise bursts followed by brief recovery periods over an extended period of time (90 minutes). Activation of both energy systems, the aerobic and anaerobic is needed to meet the muscle energy demands during the soccer game. Competitive rowing is also a sport discipline that requires highly developed aerobic and anaerobic capacity. The energy needed for a 2000 m ergometer rowing was estimated to be $65-75 \%$ aerobic and $25-35 \%$ anaerobic. ${ }^{25}$ Anaerobic power is specifically important at the beginning and final dash and characteristically ensures $20-30 \%$ of the energy requirement of a 2000 m race. ${ }^{26}$ 
Table 2. Wingate anaerobic test parameters in athletes and non athletes.

\begin{tabular}{|c|c|c|c|c|c|c|c|}
\hline Subjects & Parameter & $\begin{array}{c}\text { Anaerobic power } \\
\text { (W) }\end{array}$ & $\begin{array}{c}\text { Relative anaerobic } \\
\text { power }(\mathrm{W} / \mathrm{kg})\end{array}$ & $\begin{array}{l}\text { Explosive power } \\
\text { (W/s) }\end{array}$ & $\begin{array}{c}\text { Relative explosive } \\
\text { power }(\mathrm{W} / \mathrm{kg} / \mathrm{s})\end{array}$ & $\begin{array}{l}\text { Anaerobic } \\
\text { capacity }(\mathrm{J})\end{array}$ & $\begin{array}{c}\text { Relative anaerobic } \\
\text { capacity }(\mathrm{J} / \mathrm{kg})\end{array}$ \\
\hline \multirow{4}{*}{ Non athletes } & $x$ & 558 & 6.91 & 83.8 & 1.04 & 11722 & 145 \\
\hline & SD & 107 & 1.29 & 25.4 & 0.31 & 2120 & 25.1 \\
\hline & $\min$ & 308 & 3.54 & 34.2 & 0.39 & 6620 & 76.1 \\
\hline & $\max$ & 750 & 9.07 & 133 & 1.60 & 15485 & 183 \\
\hline \multirow{4}{*}{ Rowers } & $x$ & 735 & 8.56 & 115 & 1.34 & 16000 & 186 \\
\hline & SD & 65.3 & 0.70 & 18.3 & 0.22 & 1039 & 12.8 \\
\hline & $\min$ & 629 & 7.31 & 79.8 & 0.93 & 14025 & 171 \\
\hline & $\max$ & 824 & 9.77 & 143 & 1.75 & 17695 & 213 \\
\hline \multirow{4}{*}{ Soccer players } & $x$ & 748 & 9.63 & 110 & 1.41 & 15481 & 200 \\
\hline & SD & 122 & 1.68 & 33.4 & 0.39 & 2774 & 34.1 \\
\hline & $\min$ & 576 & 5,60 & 36.7 & 0.63 & 12425 & 123 \\
\hline & $\max$ & 973 & 13.7 & 173 & 2,05 & 19690 & 272 \\
\hline \multirow{4}{*}{ Wrestlers } & $x$ & $836^{*}$ & 10.0 & $139 *$ & $1.65^{*}$ & 16560 & 199 \\
\hline & SD & 152 & 1.70 & 34.1 & 0.33 & 2260 & 31.9 \\
\hline & $\min$ & 563 & 6.13 & 76.9 & 1.03 & 11605 & 131 \\
\hline & $\max$ & 1136 & 12.3 & 215 & 2.17 & 20825 & 258 \\
\hline
\end{tabular}

${ }^{*} \mathrm{p}<0.05$.

Lower values of peak power in rowers compared to wrestlers colud be explaned by the repetitive nature of rowing, where in contrast to "instantaneous" events such as throwing and jumping, rowers are not specifically trained to produce such explosive power outputs. Thus very high peak power values may be less important in rowing probably due to the prolonged nature of the sport. But, due to a large contribution of anaerobic metabolic processes, efficiency of anaerobic energy pathways may also be a significant predictor of rowing performance. ${ }^{27}$ When analyzing the scores of wrestlers and comparing to another studies, the mean peak power of male wrestlers was $10,1 \mathrm{~W} \cdot \mathrm{kg}^{-1}$ in our study group. In a previous study, lower peak power values were reported, ${ }^{28}$ and age difference and shorter sport experience could be considered as contributing factors to these differences. However, peak power values in our study seem to be similar to other reports. For example a study of elite senior wrestlers above 20 years old, peak anaerobic power for legs was reported as $10.8 \mathrm{~W} \cdot \mathrm{kg}^{-1)} 29$ and these findings were consistent with our Wingate results.

New parameter of Wingate Anaerobic Test was significantly higher in predominantly anaerobic activity such is wrestling in which explosive movements play great role, and energy is provided mostly via glycolysis and from creatine phosphate energy releasing system. Glycolytic muscle enzyme levels and ionic transport systems are major determinants of anaerobic muscle performance, both when expressed as anaerobic power and capacity. ${ }^{24}$ Explosive power presented a new dimension of anaerobic power, i.e., how fast maximal energy for power development can be obtained, which of particular importance in sports activities that demand explosiveness and fast maximal energy production, such is wrestling. This parameters shows similar distribution among groups as anaerobic power. According to Campeiz and Oliveira, ${ }^{30}$ the anaerobic power represents the potential to generate energy through the alactic anaerobic system (ATP-CP), depleted in 5 to 10 seconds, its maximum peak being reached between 1 and 5 seconds and characterized by explosive movements.
Each of recorded Wingate parameters can be improved separately by specific training regimes, but increase in any of them leads to improvement in others because of their interconnection as a components of anaerobic capacity. It has also been suggested that a high level of aerobic capacity is a prerequisite for increased anaerobic performance during sustained intermittent activities. ${ }^{24}$ For this reason, it is very important to incorporate both aerobic and anaerobic training into overall conditioning training protocols. For instance, muscle strength training, combined with technical training could improve and athlete,s power output during explosive activities. ${ }^{24,30}$

These physiological variables do not necessarily predict success in a sport, where strategy, technique, tactics and motivation are also essential elements of maximal result, but could be used by exercise physiologist, trainers, or athletes as a reference of conditioning and monitoring training process or rehabilitation status.

\section{CONCLUSIONS}

Explosive power presented a new dimension of anaerobic power, and its values are high in all sports activities that demand explosiveness and fast maximal energy production, such is wrestling. Our results indicate that wrestlers reached greater alactic anaerobic power in relation to rowers and soccer players where anaerobic endurance played more important role, and that the importance of the characteristics and specific training of the sports probably contribute to the determination of the predominant metabolic medium during the practice.

As a concludion, physiological determinants like explosive power, which are affected by anaerobic energy pathways should also be incorporated in the planning of training processes, performance prediction and talent identification in sport.

All authors declare no potential conflict of interest related to this article.

AUTHORS' CONTRIBUTIONS: Each author made significant individual contributions to this manuscript. DKJ (0000-0001-5739-3237)*: was the main contributor in the drafting of the manuscript and also tested and analyzed data. GJ (000-003-4899-4748)*, MBC (000-0002-9610-313X)* and ME (0000-0001-9214-384X)*: collected and evaluated the statistical analysis data and also performed the literature search. NP (0000-0001-8460-6402)* and GD (0000-0003-4675-6850)* reviewed the manuscript and prepared the final version for publication. All authors reviewed the manuscript, agree with everything stated in the manuscript, and approve the final version for publication. ${ }^{*} \mathrm{ORCID}$ (Open Researcher and Contributor ID). 


\section{REFERENCES}

1. Fox EL, Bowers RW, Foss ML. The Physiological Basis of Physical Education and Athletics. 5th ed. Philadelphia: W.B. Saunders; 1993.

2. Inbar O, Bar-Or O, Skinner JS. The Wingate Anaerobic Test. Champaign, IL: Human Kinetics; 1996.

3. Medbø Jl, Mohn AC, Tabata I, Bahr R, Vaage O, Sejersted OM. Anaerobic capacity determined by maximal accumulated $\mathrm{O}_{2}$ deficit. J Appl Physiol. 1988; 64(1):50-60.

4. KaczkowskiW, Montgomery DL, Taylor AW, Klissouras V. The relationship between muscle fiber composition and maximal anaerobic power and capacity. J Sports Med Phys Fitness. 1982;22(4):407-13.

5. Sands WA, MCNeal JR, Ochi MT, Urbanek TL, Jemni M, Stone MH. Comparison of the Wingate and Bosco anaerobic tests. J Strength Cond Res. 2004;18(4):810-5.

6. Beneke R, Pollmann C, Bleif I, Leithäuser RM, Hütler M. How anaerobic is the Wingate Anaerobic Test for humans? Eur J Appl Physiol. 2002;87(4-5):388-92.

7. Lovell D, Kerr A, Wiegand A, Solomon C, Harvey L, McLellan C. The contribution of energy systems during the upper body Wingate anaerobic test. Appl Physiol Nutr Metab. 2013;38(2):216-9.

8. Bar-Or. The Wingate Anaerobic Test. An update on methodology, reliability, and validity. Sports Med. 1987;4(6):381-94.

9. Chromiak JA, Smedley B, Carpenter W, Brown R, Koh YS, Lamberth JG, et al. Effect of a 10-week strength training program and recovery drink on body composition, muscular strength and endurance, and anaerobic power and capacity. Nutrition. 2004;20(5):420-7.

10. Barfield JP, Sells PD, Rowe DA, Hannigan-Downs K. Practice effect of the Wingate anaerobic test. J Strength Cond Res. 2002;16(3):472-3.

11. Hoffman J, Epstein S, Einbinder M, Weinstein Y. A Comparison Between the Wingate Anaerobic Power Test to Both Vertical Jump and Line Drill Tests in Basketball Players. J Strength Cond Res. 2000;14(3):261-4.

12. Häkkinen $K$, Komi PV, Alén M. Effect of explosive type strength training on isometric force- and relaxation-time, electromyographic and muscle fibre characteristics of leg extensor muscles. Acta Physiol Scand. 1985;125(4):587-600.

13. Dotan R, Bar-Or O. Load optimization for the Wingate Anaerobic Test. Eur J Appl Physiol Occup Physiol. 1983;51(3):409-17

14. Maud PJ, Shultz BB. Norms for the Wingate anaerobic test with comparison to another similar test. Res Q Exerc Sport. 1989;60(2):144-51.
15. Bauer T, Thayer RE, Baras G. Comparison of training modalities for power development in the lower extremity. J Strength Cond Res. 1990;4(4):115-21.

16. Newton RU, Kraemer WJ. Developing Explosive Muscular Power: Implications for a Mixed Methods Training Strategy. Strength Cond J. 1994;16(5):20-31.

17. Al-Hazzaa HM, Almuzaini KS, Al-Refaee SA, Sulaiman MA, Dafterdar MY, Al-Ghamedi A, et al. Aerobic and anaerobic power characteristics of Saudi elite soccer players. J Sports Med Phys Fitness. 2001;41(1):54-61.

18. Apostolidis N, Nassis GP, Bolatoglou T, Geladas ND. Physiological and technical characteristics of elite young basketball players. J Sports Med Phys Fitness. 2004;44(2):157-63.

19. Kocak S, Karli U. Effects of high dose oral creatine supplementation on anaerobic capacity of elite wrestlers.J Sports Med Phys Fitness. 2003:43(4):488-92.

20. Young W. The planning of resistance training for power sports. Strength Cond J. 1991;13(4):26-9.

21. Vardar SA, Tezel S, Oztürk L, Kaya O. The relationship between body composition and anaerobic performance of elite young wrestlers. J Sports Sci Med. 2007;6:34-8.

22. Yoon J. Physiological profiles of elite senior wrestlers. Sport Med. 2002;32(4):225-33.

23. Pennington C. Determining the Anaerobic Power Output Differences between the Genders in Untrained Adults. Am Int J Contemp Res. 2014;4(4):64-77.

24. Bangsbo J, Nørregaard L, Thorsø F. Activity profile of competition soccer. Can J Sport Sci. 1991;16(2):110-6.

25. Droghetti $P$, Jensen $K$, Nilsen TS. The total estimated metabolic cost of rowing. FISA Coach. 1991;2(2):1-4.

26. Secher NH. Physiological and biomechanical aspects of rowing. Implications for training. Sports Med. 1993;15(1):24-42.

27. Akca F. Prediction of Rowing Ergometer Performance from Functional Anaerobic Power, Strength and Anthropometric Components. J Hum Kinet. 2014;41:133-42.

28. Horswill CA, Scott JR, Galea P. Comparison of maximum aerobic power, maximum anaerobic power, and skinfold thickness of elite and nonelite junior wrestlers. Int J Sports Med. 1989;10(3):165-8.

29. Horswill CA, Miller JE, Scott JR, Smith CM, Welk G, Van Handel P. Anaerobic and aerobic power in arms and legs of elite senior wrestlers. Int J Sports Med. 1992;13(8):558-61.

30. Campeiz JM, Oliveira PR. Análise comparativa de variáveis antropometricas e anaeróbias de futebolistas profissionais, juniores e juvenis. Movimento \& Percepção. 2006;6(8). 